\title{
One-bottle adhesives: in vitro analysis of solvent volatilization and sealing ability
}

\section{Adesivos de frasco único: análise in vitro da volatilização do solvente e do selamento marginal}

\author{
Fábio Garcia Lima* \\ Rafael Ratto de Moraes** \\ Flávio Fernando Demarco*** \\ Francisco Augusto Burkert Del Pino**** \\ John Powers $* * * * *$
}

\begin{abstract}
The aim of this study was to compare the solvent volatilization rate and evaluate the sealing ability of different one-bottle adhesives that were in constant clinical use - an ethanol/water-based adhesive (Single Bond, 3M/ESPE - SB) and an acetone-based adhesive (Prime \& Bond 2.1, Dentsply/Caulk - PB). Nine bottles of each agent were collected from the clinics of a dental school, and new ones were used as controls. The weight of all bottles and of empty bottles was determined using an analytical balance. A drop of each solution was dispensed onto the balance, taking its initial weight (IW) and, after $10 \mathrm{~min}$, its final weight (FW). The IW/FW ratio was used to determine the solvent's volatilization rate. The bottles with the highest evaporation levels (SB Control and PB Control) and with the lowest evaporation levels (SB Test and PB Test) of each agent were applied in Class V restorations with margins in dentin. Specimens were thermocycled and immersed in a $0.5 \%$ basic fuchsin solution. Dye penetration was evaluated under magnification and the data were submitted to the Kruskal-Wallis test. Solvent volatilization was faster for the acetone-based adhesive. IW/FW ratios ranged from 1.239 to 1.515 for SB, and from 3.488 to 6.476 for PB. The PB-Control and SB-Control groups exhibited similar microleakage patterns. The highest dye penetration scores were found for the PB-Test group $(\mathrm{p}<0.05)$. Results indicate that the sealing ability can be affected by the repeated opening of acetone-based adhesive bottles.
\end{abstract}

DESCRIPTORS: Dentin-bonding agents; Dental leakage; Solvents; Evaporation.

\begin{abstract}
RESUMO: O objetivo deste estudo foi comparar a taxa de volatilização do solvente e a capacidade de selamento de diferentes adesivos de frasco único que estavam em constante uso clínico - um à base de etanol/água (Single Bond, 3M/ESPE) e um à base de acetona (Prime \& Bond 2.1, Dentsply/Caulk). Nove frascos de cada agente foram coletados das clínicas da faculdade e outros novos foram utilizados como controle. Os pesos de todos os frascos e de frascos vazios foram determinados em uma balança analítica. Uma gota de cada solução foi dispensada na balança, tomando-se seu peso inicial (PI) e, após $10 \mathrm{~min}$, seu peso final (PF). A razão PI/PF foi utilizada para determinar a taxa de volatilização do solvente. Os frascos com os maiores nivveis de evaporação (SB Controle e PB Controle) e com os menores niveis de evaporação (SB Teste e PB Teste) foram aplicados em restaurações Classe V com margens em dentina. Os espécimes foram termociclados e imersos em solução de fucsina básica a $0,5 \%$. A penetração do corante foi avaliada sob magnificação e os dados foram submetidos ao teste de Kruskal-Wallis. A volatilização do solvente foi mais rápida para o adesivo à base de acetona. As razões PI/PF variaram de 1,239 a 1,515 para SB e de 3,488 a 6,476 para PB. PB-Controle e SB-Controle exibiram vedamento similar. Os maiores escores de penetração foram encontrados para o PB-Teste $(p<0,05)$. Os resultados indicam que a habilidade de selamento pode ser afetada pela repetida utilização dos frascos de adesivo à base de acetona.
\end{abstract}

DESCRITORES: Adesivos dentinários; Infiltração dentária; Solventes; Evaporação.

\section{INTRODUCTION}

Continual evolution of adhesive systems has resulted in the last few years in dentin bond strengths very similar to those verified in enam$\mathrm{el}^{21}$. Micro-mechanical interlocking with a hybrid layer ${ }^{13}$ is currently accepted as the major mechanism of resin bonding to dentin. However, care is needed to correctly use the adhesive systems to obtain high quality of hybridization ${ }^{7,19}$, mainly

*Doctorate Student, Department of Operative Dentistry; **Undergraduate Student; ***PhD, Professor, Department of Operative Dentistry, ${ }^{* * *} \mathrm{PhD}$, Professor, Department of Biochemistry - School of Dentistry, Federal University of Pelotas. ***** PhD, Professor and Director, Houston Biomaterials Research Center, The University of Texas Dental Branch at Houston. 
Lima FG, Moraes RR, Demarco FF, Del Pino FAB, Powers J. One-bottle adhesives: in vitro analysis of solvent volatilization and sealing ability. Braz Oral Res 2005;19(4):278-83.

when dealing with a moist substrate and using an organic solvent ${ }^{17}$.

Hybridization can be obtained after acid etching and penetration of a fluid resin into nanochannels among collagen fibers, created by dissolution of hydroxyapatite ${ }^{4,13}$. However, in the wet-bonding technique proposed by Kanca ${ }^{11}$ (1992), these channels have approximately $70 \%$ of their volume filled by water ${ }^{16}$. Thus, the mechanism needs a vehicle that can remove the excess water and, at the same time, transport the polymerizable monomers into the open dentin tubules and the nanospaces in the collagen network ${ }^{8,16,17}$.

Several simplified dentin/enamel adhesives have been introduced, with different solvents (water, ethanol or acetone) to enhance the penetration of the fluid resin into the moist, demineralized dentin substrate ${ }^{17,18}$. However, these vehicles are volatile and may easily evaporate during the repeated use of bottles in a clinical environment ${ }^{19}$. The reduction of solvent content could decrease the reactivity of the adhesive in moist dentin, leading to incomplete monomer infiltration and incomplete water displacement ${ }^{21}$, which could compromise adhesion.

Based on these facts, the hypothesis tested in this study was that the repeated use of one-bottle adhesives in a clinical environment could lead to solvent evaporation that could impair the bonding ability to dentinal substrate. This study compared the solvent volatilization rate of two different solvent-based adhesives that were in constant clinical use, and evaluated the ability of these solutions in sealing dentin margins of resin composite restorations.

\section{MATERIAL AND METHODS Evaporation test}

Two different one-bottle adhesive systems were investigated: an ethanol/water-based adhesive (SB: Single Bond, 3M ESPE, St. Paul, MN, USA) and an acetone-based adhesive (PB: Prime \& Bond 2.1, Dentsply Caulk, Milford, DE, USA). Nine bottles of each adhesive were collected from the Dental Clinics of the Federal University of Pelotas, RS, Brazil. These adhesives had been in use for undetermined time periods, presenting different contents of bonding solution. Materials composition is shown in Table 1. A new bottle of each agent was used as a control.

All procedures were performed in a laboratory with controlled humidity and temperature. Initially, the weights of all bottles, and of an empty bottle for each solution, were determined using an analytical digital balance (AG-200, Gehaka, São Paulo, SP, Brazil), in order to verify the net weight of the adhesive (real weight). Then, a drop of each bonding agent was dispensed onto the balance, taking its initial weight (IW) and its corrected weight every minute over 10 minutes, after which the final weight (FW) was determined. Similar procedures were performed to verify the evaporation of $0.1 \mathrm{ml}$ of pure acetone and ethanol in the balance. The ratio IW/FW was used to verify the loss in mass and to compare the solvent volatilization rates between all bottles.

\section{Microleakage test}

Two bottles of each agent were selected for the microleakage evaluation: the ones with the highest evaporation levels (SB Control and PB Control) and the ones with the lowest levels (SB Test and PB Test), as shown in Table 2.

Recently extracted bovine incisors were obtained. The pulp tissue was removed, apical openings were occluded with epoxy resin (Poxilina Acapol, Buenos Aires, Argentina), and the teeth were stored in a sodium azide solution (Basa, Caxias do Sul, RS, Brazil) at $37^{\circ} \mathrm{C}$ for no more than 10 days. Standard Class V cavities $(2 \times 2 \times 2 \mathrm{~mm})$

TABLE 1 - Composition of dentin bonding solutions.

\begin{tabular}{l|l|l}
\hline \hline Adhesive & Manufacturer & \multicolumn{1}{|c}{ Chemical composition } \\
\hline $\begin{array}{l}\text { Single } \\
\text { Bond }\end{array}$ & $\begin{array}{l}\text { 3M ESPE, St. } \\
\text { Paul, MN, USA }\end{array}$ & $\begin{array}{l}\text { Water, ethanol, } \\
\text { HEMA, BisGMA, } \\
\text { dimethacrylates, } \\
\text { polyalkenoic acid } \\
\text { copolymer }\end{array}$ \\
\hline $\begin{array}{l}\text { Prime \& } \\
\text { Bond 2.1 }\end{array}$ & $\begin{array}{l}\text { Dentsply } \\
\text { Caulk, } \\
\text { Milford, DE, } \\
\text { USA }\end{array}$ & $\begin{array}{l}\text { Acetone, elastomeric } \\
\text { resin, PENTA, } \\
\text { cetylamine } \\
\text { hydrofluoride }\end{array}$ \\
\hline \hline
\end{tabular}

TABLE 2 - Groups submitted to the microleakage test.

\begin{tabular}{c|c|l}
\hline \hline Group & $\mathrm{N}$ & \multicolumn{1}{|c}{ Description } \\
\hline SB Control & 10 & $\begin{array}{l}\text { Highest IW } / \mathrm{FW} \text { ratio } \\
\text { for Single Bond }\end{array}$ \\
\hline SB Test & 10 & $\begin{array}{l}\text { Lowest IW /FW ratio } \\
\text { for Single Bond }\end{array}$ \\
\hline PB Control & 10 & $\begin{array}{l}\text { Highest IW /FW ratio } \\
\text { for Prime \& Bond } 2.1\end{array}$ \\
\hline PB Test & 10 & $\begin{array}{l}\text { Lowest IW /FW ratio } \\
\text { for Prime \& Bond } 2.1\end{array}$ \\
\hline \hline
\end{tabular}

$\mathrm{IW}=$ initial weight. $\mathrm{FW}=$ final weight. 
Lima FG, Moraes RR, Demarco FF, Del Pino FAB, Powers J. One-bottle adhesives: in vitro analysis of solvent volatilization and sealing ability. Braz Oral Res 2005;19(4):278-83.

were made on the incisors' roots, with all margins placed in dentin. Cavities were prepared with \#330 carbide burs (KG Sorensen, Barueri, SP, Brazil) in high speeds, under air-water cooling. The burs were replaced after every four preparations in order to ensure high cutting efficacy.

Cavities were then cleaned with a cotton pellet and detergent (Tergensol, Inodon, Porto Alegre, RS, Brazil). The adhesive procedures followed the manufacturers' instructions, and absorbent paper was used to remove excess dentin moisture. Restorations (Filtek Z250 composite resin, 3M ESPE) were made in three increments, each one of them light-activated for 40 seconds (XL 3000, 3M ESPE, $480 \mathrm{~mW} / \mathrm{cm}^{2}$ ). Finishing and polishing were performed using multi-laminated burs (KG Sorensen) and aluminum oxide discs (Sof-lex system, 3M ESPE).

Specimens were thermocycled (500 cycles between $5 \pm 2{ }^{\circ} \mathrm{C}$ and $55 \pm 2{ }^{\circ} \mathrm{C}$, dwell time of 30 seconds). Then, all surfaces were isolated with a double layer of nail varnish (except the restorations and $1 \mathrm{~mm}$ surrounding them), and the specimens were immersed in a $0.5 \%$ basic fuchsin solution (Natura, Pelotas, RS, Brazil) for 24 hours at room temperature, followed by a wash in tap water for 24 hours. Each tooth was sectioned longitudinally through the center of the restorations. The dye penetration was evaluated under magnification (40 X) by two calibrated examiners, using standard scores: 0 (no penetration), 1 (dye agent penetration up to the middle of the lateral cavity wall), 2 (penetration up to $2 / 3$ of the lateral cavity wall) and 3 (penetration reaching the cavity floor). When disagreement occurred between examiners, consensus was obtained. Data were submitted to a non-parametric Kruskal-Wallis test with a confidence level of $95 \%$.

\section{RESULTS \\ Evaporation test}

Tables 3 and 4 exhibit the adhesive weight (real weight - RW), bulk percentage, initial weight (IW), final weight (FW) and IW/FW ratio for the ethanol/water-based and acetone-based adhesives, respectively. During the weighing procedures, it was noted that, for all Single Bond bottles, there was no change in the drops' weight after 7 minutes in the balance, while for Prime \& Bond 2.1 the same finding was observed after only 3 minutes. Similarly, no significant weight alteration was observed after 3 and 7 minutes, respectively for drops
TABLE 3 - Real weight (g), bulk percentage, initial weight (IW) (g), final weight (FW) (g), and IW/FW ratio for all Single Bond bottles.

\begin{tabular}{c|c|c|c|c|c}
\hline \hline Group & $\begin{array}{c}\text { Real } \\
\text { Weight }\end{array}$ & Bulk \% & IW & FW & $\begin{array}{c}\text { IW/FW } \\
\text { ratio }\end{array}$ \\
\hline $\begin{array}{c}\text { SB } \\
\text { Control }\end{array}$ & 6.7838 & 100 & 0.0203 & 0.0134 & 1.515 \\
\hline SB & 5.6687 & 83.56 & 0.0215 & 0.0143 & 1.504 \\
\hline SB & 6.1113 & 90.09 & 0.0219 & 0.0146 & 1.500 \\
\hline SB & 6.7403 & 99.36 & 0.0218 & 0.0147 & 1.483 \\
\hline SB & 6.0195 & 88.73 & 0.0212 & 0.0144 & 1.472 \\
\hline SB & 4.6290 & 68.24 & 0.0204 & 0.0141 & 1.447 \\
\hline SB & 5.9954 & 88.38 & 0.0246 & 0.0176 & 1.398 \\
\hline SB & 6.3116 & 93.04 & 0.0229 & 0.0174 & 1.316 \\
\hline SB & 6.3803 & 94.05 & 0.0206 & 0.0158 & 1.304 \\
\hline SB Test & 0.4119 & 6.07 & 0.0295 & 0.0238 & 1.239 \\
\hline \hline
\end{tabular}

TABLE 4 - Real weight (g), bulk percentage, initial weight (IW) (g), final weight (FW) (g), and IW/FW ratio for all Prime $\&$ Bond 2.1 bottles.

\begin{tabular}{c|c|c|c|c|c}
\hline \hline Group & $\begin{array}{c}\text { Real } \\
\text { Weight }\end{array}$ & Bulk \% & IW & FW & $\begin{array}{c}\text { IW/FW } \\
\text { ratio }\end{array}$ \\
\hline $\begin{array}{c}\text { PB } \\
\text { Control }\end{array}$ & 4.2727 & 100 & 0.0136 & 0.0021 & 6.476 \\
\hline PB & 1.7852 & 41.78 & 0.0135 & 0.0027 & 5.000 \\
\hline PB & 3.5291 & 82.60 & 0.0146 & 0.0032 & 4.563 \\
\hline PB & 2.8450 & 66.59 & 0.0182 & 0.0040 & 4.550 \\
\hline PB & 1.1728 & 27.45 & 0.0177 & 0.0039 & 4.538 \\
\hline PB & 3.9821 & 93.20 & 0.0156 & 0.0035 & 4.457 \\
\hline PB & 3.1367 & 73.41 & 0.0121 & 0.0028 & 4.321 \\
\hline PB & 3.2190 & 75.34 & 0.0165 & 0.0039 & 4.231 \\
\hline PB & 3.5018 & 81.96 & 0.0179 & 0.0043 & 4.163 \\
\hline PB Test & 2.8508 & 66.72 & 0.0150 & 0.0043 & 3.488 \\
\hline \hline
\end{tabular}

of pure acetone and pure ethanol dispensed onto the balance.

The IW/FW ratio, according to Tables 3 and 4, varied from 1.239 to 1.515 among Single Bond samples, and from 3.488 to 6.476 among Prime \& Bond 2.1 specimens. For both groups, the highest IW/FW ratios were found for the control groups (new bottles).

\section{Microleakage test}

Scores for dye penetration in the dentin margins for the different groups are shown in Table 5 . 
Lima FG, Moraes RR, Demarco FF, Del Pino FAB, Powers J. One-bottle adhesives: in vitro analysis of solvent volatilization and sealing ability. Braz Oral Res 2005;19(4):278-83.

TABLE 5 - Dye penetration scores.

\begin{tabular}{c|c|c|c|c|c}
\hline \hline Group & $\begin{array}{c}\text { Score } \\
0\end{array}$ & $\begin{array}{c}\text { Score } \\
1\end{array}$ & $\begin{array}{c}\text { Score } \\
2\end{array}$ & $\begin{array}{c}\text { Score } \\
3\end{array}$ & $\mathrm{p}$ \\
\hline $\begin{array}{c}\text { SB } \\
\text { Control }\end{array}$ & 8 & 1 & 1 & - & $>0.05$ \\
\hline SB Test & 6 & 4 & - & - & $>0.05$ \\
\hline $\begin{array}{c}\text { PB } \\
\text { Control }\end{array}$ & 6 & 2 & - & 2 & $>0.05$ \\
\hline PB Test & 2 & 3 & 1 & 4 & $=0.024$ \\
\hline \hline
\end{tabular}

Despite the difference in the IW/FW ratios between SB samples, no significant differences were found between control and experimental groups. However, significant differences were observed between PB Control and PB Test groups, since the latter exhibited the highest dye penetration scores among all groups $(p<0.05)$. PB Control was similar to SB Control and SB Test.

\section{DISCUSSION}

Resin bonding to acid-etched dentin depends upon the uptake of liquid monomers into the interfibrilar spaces previously occupied by apatite crystals $^{4,13}$. Solvents behave like a water chaser, allowing the resin monomers to penetrate into the demineralized, moist dentin substrate. However, due to the natural volatile characteristics of these vehicles, their concentration in one-bottle adhesives may decrease with time. High frequency of use, in association with high temperatures, might accelerate this process $^{21}$, which could lead to poor hybridization and interfere with bond strength $^{3,21}$.

Microleakage of resin composites has been a significant concern for clinicians, especially with restoration margins located in dentin ${ }^{24}$. These tests are commonly used to verify the quality of adhe$\operatorname{sion}^{19}$, and can be related to pulp pathology, hypersensitivity, secondary decay ${ }^{12}$, marginal staining ${ }^{2}$ and degradation of bond area ${ }^{5,9}$. The dye penetration test selected in the present study, according to Raskin et al. ${ }^{20}$ (2001), is the most frequently employed method found in the literature to assess the sealing ability of restorative materials. Measurement of leakage by software analysis means has been indicated to provide quantitative evaluation of microleakage, allowing the use of parametric statistics ${ }^{12}$. However, when comparing this method to the qualitative method (scores), Veronezi et al. ${ }^{26}$ (2002) found no significant difference in both mean and maximum values of microleakage.
The hypothesis that the repeated use of onebottle adhesives could lead to solvent evaporation and impair bonding ability was partially confirmed. Our outcomes reveal that the acetone-based adhesive was more sensitive to repeated use than the ethanol/water-based one, showing a severe loss of solvent. In addition, the group with the lowest IW/ FW ratio for Prime \& Bond 2.1, i.e., with the lowest solvent content, presented the poorest sealing ability among all groups. This result is probably related to a reduced solvent content for this bottle, which promoted an insufficient water removal from exposed collagen mesh and incomplete monomer diffusion through the demineralized dentin. Water is well recognized to decrease the conversion degree of adhesive monomers, and also to have dramatic effects on the bond strength ${ }^{10}$. In addition, excess moisture competes with hydrophilic monomers for space within the demineralized den$\operatorname{tin}^{10,14}$, resulting in a lack of complete adhesive resin infiltration ${ }^{23}$.

Furthermore, it has been demonstrated that, under excess moisture conditions, bonding solutions may undergo phase separation, which inhibits the formation of an integrated collagen/polymer network and compromises the structural integrity of the resultant hybrid layer ${ }^{23}$. This phase separation could also result in regional variations in adhesive composition and thus affect the curing performance, strength and durability of the resin infiltrated zone ${ }^{10,23}$, which could also explain our results.

For Single Bond, the solvent corresponds to $30 \%$ of adhesive volume, while for Prime $\&$ Bond 2.1 this value increases to $80 \%{ }^{21}$. Thus, one could expect that Single Bond would be more sensitive to repeated use. Nonetheless, there was no significant difference in dye penetration among SB groups, even for the bottle containing only $6 \%$ of adhesive solution mass. We speculate that this is related to a relatively continuous solvent/monomer ratio in SB bottles even after repeated use, whereas Prime $\&$ Bond 2.1 bottles might have experienced an alteration of this ratio as a function of a high solvent loss with time.

The probable main reason for these differences lays in the fact that acetone has higher vapor pressure $(180 \mathrm{mmHg})$ and lower boiling temperature $\left(56.5^{\circ} \mathrm{C}\right)$ when compared to ethanol $(43.9 \mathrm{mmHg}$; $\left.78.3^{\circ} \mathrm{C}\right)$ and water $\left(17.5 \mathrm{mmHg} ; 100^{\circ} \mathrm{C}\right)^{1,6}$, resulting in easier evaporation. According to our results, after only 3 minutes in the balance, pure acetone and Prime $\&$ Bond 2.1 drops achieved their final weight, while pure ethanol and Single Bond drops 
Lima FG, Moraes RR, Demarco FF, Del Pino FAB, Powers J. One-bottle adhesives: in vitro analysis of solvent volatilization and sealing ability. Braz Oral Res 2005;19(4):278-83.

took 7 minutes. Another explanation is that Single Bond is an ethanol/water-based adhesive, and the mixture of water with an organic solvent provides more stability to the solution ${ }^{1}$. Previous reports confirm that acetone-based adhesives are more sensitive to repeated application than ethanol/ water-based ones. Perdigão et al. ${ }^{19}$ (1999) found higher shear bond strengths after 30 days of repeated use for Single Bond when compared to an acetone-based adhesive (One-Step, Bisco Dental Products, Itasca, IL, USA).

Nevertheless, it is important to highlight that the specimens of bonding agents tested here were collected from a dental clinic where the bottles were in constant manipulation by dental students. In such a situation, they could have remained open for uncertain time periods, allowing solvent evaporation. Corroborating our findings, Perdigão et al. ${ }^{19}$ (1999) observed a decrease in shear bond strength for One-Step after 30 days of repeated use, and Gallo et al. ${ }^{6}$ (2001) found that acetone-based adhesives showed a trend toward decreased bond strengths when the bonding agents were dispensed 10 minutes before their application.

\section{REFERENCES}

1. Abate PF, Rodriguez VI, Macchi RL. Evaporation of solvent in one-bottle adhesives. J Dent 2000;28(6):437-40.

2. Alani AH, Toh CG. Detection of microleakage around dental restorations: a review. Oper Dent 1997;22(4):173-85.

3. Cho BH, Dickens SH. Effects of the acetone content of single solution dentin bonding agents on the adhesive layer thickness and the microtensile bond strength. Dent Mater 2004;20(2):107-15.

4. Eick JD, Gwinnett AJ, Pashley DH, Robinson SJ. Current concepts on adhesion to dentin. Crit Rev Oral Biol Med 1997;8(3):306-35.

5. Gagliardi RM, Avelar RP. Evaluation of microleakage using different bonding agents. Oper Dent 2002;27(6):582-6.

6. Gallo JR, Burgess JO, Xu X. Effect of delayed application on shear bond strength of four fifth-generation bonding systems. Oper Dent 2001;26(1):48-51.

7. Gallo JR, Comeaux R, Haines B, Xu X, Burgess JO. Shear bond strength of four filled dentin bonding systems. Oper Dent 2001;26(1):44-7.

8. Gregoire GL, Bernadette AA, Millas A. Interfacial micromorphological differences in hybrid layer formation between water- and solvent-based dentin bonding systems. J Prosthet Dent 2002;87(6):633-41.

9. Grossman ES, Sparrius O. Marginal adaptation of composite resin-restored dentinal cavities. J Prosthet Dent 1990;64(5):519-22.

10. Jacobsen T, Söderholm KJ. Some effects of water on dentin bonding. Dent Mater 1995;11(2):132-6.

11 . Kanca $\mathrm{J} 3^{\text {rd }}$. Resin bonding to wet substrate. 1 . Bonding to dentin. Quintessence Int 1992;23(1):39-41.
On the other hand, when comparing control specimens, both adhesive systems exhibited similar sealing ability, which is in line with several studies ${ }^{5,21,25}$. However, other authors have found differences between distinct solvent-based systems. Nunes et al. ${ }^{15}$ (2001) and Ritter et al. ${ }^{22}$ (2001) reported higher shear bond strengths for ethanol-based adhesives, while Gregoire et al. ${ }^{8}$ (2002) observed better adaptation between monomer tags and tubule walls using acetone-based ones.

\section{CONCLUSION}

The results obtained in the present study have clinical significance. New bottles of both tested agents produced similar microleakage results. However, the acetone-based adhesive (Prime \& Bond 2.1) proved to be more sensitive to solvent loss, and the sealing ability could be affected by the repeated use of this solution. Thus, clinicians should be aware of the importance of keeping the bottles closed when not in use.

12. Mota CS, Demarco FF, Camacho GB, Powers JM. Microleakage in ceramic inlays luted with different resin cements. J Adhes Dent 2003;5(1):63-70.

13. Nakabayashi N, Kojima K, Masuhara E. The promotion of adhesion by the infiltration of monomers into tooth substrates. J Biomed Mater Res 1982;16(3):265-73.

14. Nakaoki Y, Nikaido T, Burrow MF, Tagami J. Effect of residual water on dentin bond strength and hybridization of a one-bottle adhesive system. Oper Dent 2002;27(6):5638.

15. Nunes MF, Swift Jr EJ, Perdigão J. Effects of adhesive composition on microtensile bond strength to human dentin. Am J Dent 2001;14(6):340-3

16. Pashley DH, Carvalho RM. Dentine permeability and dentine adhesion. J Dent 1997;25(5):355-72.

17. Perdigão J, Frankenberger R. Effect of solvent and rewetting time on dentin adhesion. Quintessence Int 2001;32(5):385-90.

18. Perdigao J, Geraldeli S, Heymann HO, Rosa BT. Effect of conditioner and restorative resin on enamel bond strengths. Am J Dent 2000;13(2):88-92.

19. Perdigão J, Swift Jr EJ, Lopes GC. Effects of repeated use on bond strengths of one-bottle adhesives. Quintessence Int 1999;30(12):819-23.

20. Raskin A, D'Hoore W, Gonthier S, Degrange M, Dejou J. Reliability of in vitro microleakage tests: a literature review. J Adhes Dent 2001;3(4):295-308.

21. Reis AF, Oliveira MT, Giannini M, De Goes MF, Rueggeberg FA. The effect of organic solvents on one-bottle adhesives' bond strength to enamel and dentin. Oper Dent 2003;28(6):700-6. 
Lima FG, Moraes RR, Demarco FF, Del Pino FAB, Powers J. One-bottle adhesives: in vitro analysis of solvent volatilization and sealing ability. Braz Oral Res 2005;19(4):278-83.

22. Ritter AV, Bertoli C, Swift Jr EJ. Dentin bond strengths as a function of solvent and glutaraldehyde content. Am J Dent 2001;14(4):221-6.

23. Spencer P, Wang Y. Adhesive phase separation at the dentin interface under wet bonding conditions. J Biomed Mater Res 2002;62(3):447-56.

24. Tay FR, Gwinnett AJ, Pang KM, Wei SH. Variability in microleakage observed in a total-etch wet-bonding technique under different handling conditions. J Dent Res 1995;74(5):1168-78.
25. Velazquez E, Vaidyanathan J, Vaidyanathan TK, Houpt M, Shey Z, Von Hagen S. Effect of primer solvent and curing mode on dentin shear bond strength and interface morphology. Quintessence Int 2003;34(7):548-55.

26. Veronezi MC, Ishikiriama A, Bastos MT, Franco EB. Influence of the thermocycles and the evaluation methods in assessing the marginal microleakage of composite resin restorations. Rev Fac Odontol Lins 2002;14(1):9-18.

Received for publication on Sep 03, 2004

Sent for alterations on Feb 03, 2005 Accepted for publication on Nov 01, 2005 